\title{
'A lasting and salutary warning': Incendiarism, Rural Order and England's Last Scene of Crime Execution
}

\author{
STE VE POOLE \\ University of the West of England, Coldharbour Lane, Bristol BS16 1QY, UK
}

\begin{abstract}
Agricultural incendiarism was a perennial factor in social relations in some areas of nineteenth-century rural England and is often understood by historians as an expression of 'covert' social protest. However, such categorisation risks oversimplifying what may be diverse and locally specific factors. In 1830 , the high sheriff of Somerset presided over England's last ever scene of crime execution at the Somerset village of Kenn following the conviction of three labourers for incendiarism. This requires explanation. Crime scene executions were not only anachronistic and rare, but unfashionably brutal and expensive by this time, and were not undertaken lightly; moreover arson was soon to be removed from the list of capital statutes. Yet, oddly, the case was not obviously connected to the agenda of 'social protest' characterised by Swing as it emerged just months afterwards; indeed understanding the behaviour of the county authorities here requires an appreciation of a considerably more specific and parochial set of concerns and conditions. The Kenn incendiaries, it is argued here, were put to death at the scene of their crime to protect and uphold the principle of informing in a rural community whose dysfunctional social relations made the practice a judicial necessity.
\end{abstract}

Despite its frequency across early nineteenth-century rural England, relatively few attempts have been made by historians to quantify or fully understand agricultural incendiarism. The importance of arson as an indicator of social tension in rural affairs is nevertheless undeniable. David Jones traced a total of 671 assize committals for arson in ten Southern counties during the 1840s alone; a figure which at least confirms the seriousness with which contemporaries viewed an offence which, in Jones's phrase, had by then assumed 'epidemic proportions'. 'With the exception of John Archer's landmark study of East Anglian fire-raising however, and a scattering of subsequent local studies in other eastern counties, it has been an epidemic largely unexplored or else subsumed within broader arguments about rural proletarianisation. This is odd, given the eminent suitability of incendiarism for detailed local study, and Andrew Charlesworth's plaintive call some sixteen years ago for a new 'agenda for historical studies of rural protest' informed by a comparative regional focus. Parish micro-history 
has certainly played a central role in the wider work on cultures of rural labour pioneered by Roger Wells (Burwash, Sussex) and Barry Reay (Boughton, Hearnhill and Dunkirk, Kent), but historians have sometimes found it difficult to separate arson from reductive understandings of protest. It is almost as though, despite Archer's conclusive evidence to the contrary, everything we need to know about incendiarism can be gleaned from Hobsbawm and Rudé's Captain Swing and reduced to a common denominator of nascent class development. Perhaps moreover, historians of the left have been wary of expending too much analytical energy on a prosaic expression of discontent as underhand in its form as it was unsophisticated. ${ }^{2}$

The conflation of incendiarism with the nomenclature of 'protest' has restricted most research to the disclosure of teleological trajectories between 'covert'; and 'overt' forms of action and the progressive development of class consciousness. The 'Wells-Charlesworth' debate, which posited a retreat from open to secretive acts of resistance whilst disagreeing about its timing, formed a spine for virtually all scholarly discourse about rural protest throughout the 1980s, but it foundered on unsatisfactory definitions of what constituted an 'overt' form of protest and on presumptions about the inter-relationship of collective economic grievances with all expressions of social conflict. Arson might be used against unpopular tithe collectors, rampaging landlords or the advocates of enclosure, and it might then enjoy a positive association with strikes, marches and riots and permit analysis of the relative timings of their use. But it might just as easily be used as an optional weapon in multi-causal conflicts between large and small farmers, warring local families, potato thieves and market gardeners, licensed and unlicensed publicans or sacked workers and their employers. This is not to argue that a fractured interpretation renders class obsolete as a category of explanation; rather it reminds us that class is not always reducible to protest and resistance. As Charlesworth himself has pointed out, 'conflict and protest are not one and the same thing'. 3

Historians of incendiarism, preoccupied by 'history from below', have also paid scant attention to the reactive and proactive behaviour of provincial authorities. Serious studies of the mounting frustration of magistrates, assize judges, military commanders, Lord Lieutenants, local landowners and the bewildered editors of urban newspapers over their inability to penetrate what Archer has called the 'enormous solidarity, even covert sympathy of the majority of working people towards the instigators of the fires', were called for by Charlesworth in 1991, but substantial progress has yet to be made. ${ }^{4}$ Without some consideration of the attitude of the county executive and judiciary however, the so far completely overlooked draconian measures deployed in the Somerset village of Kenn in the summer of 1830 , six months prior to Swing, are no more comprehensible than the controversial leniency exercised against the Elham machine breakers in Kent a few weeks later at Swing's commencement. ${ }^{5}$ At Kenn a small farmer and two agricultural labourers were hanged for incendiarism on a makeshift gallows erected in a field overlooking the scene of their crime. Convicted for setting fire to three wheat mows in October 1829, their execution in the summer of 1830 was to stand 'as an example to the numerous ill-disposed persons who for some time past have infested that area and adjoining parishes' ${ }^{6}$

During the eighteenth-century, non-urban execution places were frequently chosen with an intention to re-establish local authority and governance in isolated rural areas. 
Two murderers were hanged on a hill near Walthamstow in 1752 for example, thirty-two miles and a nine-mile wagon ride from the Essex county gaol, but 'a proper place, not only in point of situation but it being a place where Mr Jeffryes (their victim) often resorted'. In the South West, a woman was hanged for infanticide in the Somerset village of Stogumber in 1772 and in the same year one William Kelly was hanged for murder on a hill overlooking Chipping Campden in Gloucestershire 'before many thousand spectators', including his grieving parents who 'met him on the road to execution'. Brought thus to the scene of his crime, Kelly 'could hold out no longer but confessed'. ${ }^{8}$ The impact of confronting the condemned not only with people who might recognise them, but with a landscape for which they might feel a sentimental attachment was frequently reiterated. Two Scottish murderers were required to mount the platform for instance:

on the very spot where they poured out the blood of their victim... for a moment a view of the scene of their guilt met their eyes. The village where they resided - the fields they crossed - the bridge on which the murder was committed - the smithy - all lay stretched before their view, bright and peaceful in the morning beams as if sin had never entered the world or evil into the heart of man! ${ }^{9}$

These sentiments were mirrored closely at Kenn in the Reverend John Leifchild's recollections of the hanging many years later: 'What occasion had these men for deep sorrow and regret when brought for the last time to witness scenes familiar to them from their infancy - how often may they have paced this very spot in the innocence of childhood!'10

Unusually large crowds of onlookers were a feature of rural crime-scene hangings; some twenty thousand were recorded at a mid eighteenth-century execution at Odd Down, Somerset for example, and ten thousand at Stanton Common, Wiltshire. ${ }^{11}$ They were often also considerably more grisly than those staged on regular gallows at urban gaols. Sometimes this was simply an effect of makeshift apparatus, but sometimes too, as at Great Bedwin, Wiltshire in 1748, from the demands of exemplary justice. Here a condemned man was winched up and slowly throttled rather than being dropped from a cart, 'much after the manner which he did the poor girl'. ${ }^{12}$ Such practices declined in the early nineteenth century as public opinion turned against extravagant displays of terror in the English countryside. One of the last took place at Godalming, Surrey in 1818 when a farmer and one of his own labourers were hanged in a field before an audience of farm workers. 'The greatest part of the crowd consisted of farm servants in their usual costume', noted The Times, 'and we never observed so many smock frocks and white straw hats in our lifetime'. ${ }^{13}$ But a few weeks earlier, the same paper had counselled against local pressure to hang a man for murder in Greenwich:

It was supposed ... that the example would have been more impressive if the crime had been expiated where it was committed and if a sacrifice had been offered to justice in sight of the spot where her most sacred laws were violated. But we are not sorry that such an application was not made; we should rather have regretted a compliance with it. The public of this country, thank God, do not require that their feelings of abhorrence should be so invigorated. ${ }^{14}$

There appear to have been very few crime-scene hangings after this date. As Randall McGowen has argued, the exemplary value of all public hangings, how and wherever staged, had been controversial for half a century by the time the Kenn labourers were 
hanged, a controversy fuelled at least in part by concerns over the unpredictable behaviour of the crowd around the gallows. London's hangings had been relocated from Tyburn to Newgate Gaol during the 1780s, rough strangulation off the back of a wagon or ladder replaced with a quicker death by platform and drop, lengthy processions to the gallows abandoned, and a distance placed between audience and performance. ${ }^{15}$ In the provinces (and Somerset was no exception) most sheriffs took the process a stage further and relocated all hangings to a fixed drop on the roof or gatehouse of the county gaol, an act that almost obscured the final agonies of the condemned from the crowd below. But the deaths of the Kenn incendiaries of 1830 were as unsophisticated and barbarous as any at eighteenth-century Tyburn. The makeshift nature of the Kenn gallows was recalled by the Reverend Leifchild:

The rude apparatus for the execution, which had been hastily erected during the night, rose conspicuously to view. A cross beam had been set up under which a temporary platform had been placed upon the top of a wagon... the rope having been properly adjusted and fastened to the beam, upon a signal the wagon was drawn away and the bodies of the wretched youths remained suspended in the air. ${ }^{16}$

Paradoxically, the Kenn execution took place against a background of vigorous public petitioning for a reduction in the number of capital statutes; indeed parliament had recently received petitions praying for the relaxation of punishments for all crimes against property from a number of places in Somerset, including Bath, Axbridge, Winscombe and South Brent. Although one result of this campaign was the removal of rick-firing from the list of capital statutes in 1837 , some measure of the frustration felt by provincial authorities in their often abortive attempts to secure convictions may be seen in earlier parliamentary reforms of arson legislation. In 1828 a consolidating Act was passed which clarified as capital crimes both the firing of domestic and commercial premises, and 'unlawfully or maliciously setting fire to any stack of corn, grain, pulse, straw, hay or wood'. Since many acts of incendiarism went unwitnessed, making it difficult to establish the identity of the perpetrator, a separate Act of 1827 amplified the equal culpability of accessories before the fact, or anybody who might 'counsel, procure or command any other person to commit a felony'. This Act was used successfully at Kenn in 1830 to incriminate at least two of the defendants. ${ }^{17}$ But how are we to explain the anomalous barbarity of their execution at so late a date and in a part of the country not otherwise noted as a cradle of rural discontent?

Firstly, we need to understand the frustrations commonly felt by assize judges and provincial magistrates in dealing with an offence that presented so brazen an affront to rural social order. As Justice Allan Park told a jury in Essex, arson was a heinous crime 'done in secrecy' and 'a man does not commit a heinous crime in the face of day but at a moment when no human eye can see him'. Sir John Vaughan, who presided over the Kenn trial, had already expressed his distaste for incendiarism at the Cambridge assize in March:

Other crimes might be attended with some palliating circumstances... but this offence could originate only in the diabolical motive of injuring another without in any way benefiting the 
offender. It was perpetrated in the dead of night, at a time when the honest and peaceful are retired to rest.

Having dealt with the Kenn incendiaries in the Summer, Vaughan reprised these earlier remarks in an address at the opening of the post-Swing Winchester Special Commission in December. He urged the court to consider this 'horrible and appalling crime' in the light of 'the facility of committing it and the difficulty of detecting it', and added, 'the incendiary can suggest no motive to enlist the sympathies of our nature in his behalf'. ${ }^{18}$

Notwithstanding the perpetual unpopularity of rural arsonists with the judiciary, the Kenn execution was the first Somerset hanging in thirty years to be performed anywhere other than at the county gaol in Ilchester, the first for arson since 1813, and the first to take place at a crime scene since 1796 . The condemned procession, across forty-two miles of country from Ilchester to the gallows, involved an estimated two hundred participants, including all of the county's leading executive officers; and taken together with some fourteen thousand spectators marshalled at the gallows by two troops of Yeomanry and a special constabulary comprising every tenant farmer and landowner in the district, was undoubtedly one of the most impressive and theatrical displays of judicial authority ever seen in the county and a logistical exercise without parallel. We may go further. In all probability, the Kenn hanging was the last crime-scene execution ever seen in England. Its singularity may be measured by the refusal of any county authorities to stage similar performances during the otherwise fierce and uncompromising judicial retribution following the Swing rebellion, and despite pressure to the contrary from George Emery, Chief Constable of Somerset, and at least one of the district's military commanders. Emery, who had played a leading role in the Kenn executions, penned an open letter to The Times after news broke of the first Swing disturbances at Elham, Kent in September, declaring, 'I know of no other check than of following the example of the present High Sheriff of Somerset'. ${ }^{19}$ Colonel J. M. Muir, sent by Lord Melbourne to encourage the establishment of special constabulary forces in the troubled Western District in December, was more emphatic:

I trust I shall be pardoned for mentioning how much more effective it would be were they (Swing incendiaries) to be executed in two or three instances on the spot where the offences were committed. Executions at a county gaol are unfortunately too frequent to strike terror, but such an occurrence in an agricultural district would never be forgotten and prove a lasting and salutary warning.

He repeated this recommendation to the judges when he dined with them at the opening of the Wiltshire special commission and was 'inclined to think it will be adopted', but the High Sheriff of Wiltshire demurred. ${ }^{20}$ In fact, the only traceable later case occurred just outside Glasgow in 1841, a decade after Swing, when two railway navvies were convicted for murdering an overseer and hanged in a field beside the track.

In the early nineteenth century, Kenn, a small parish of 720 acres, was an almost entirely agricultural community. The fertile soil of the North Western Somerset levels offered rich pasturage for sheep and cattle and to a lesser extent, decent growing conditions for orchards, corn and market gardening. But throughout the eighteenth century, its lowlying and boggy nature, and the proximity of the coast, had made it severely prone to flooding. Enclosure at Kenn in 1811 was driven primarily by the desire of the absentee 
lords of the manor, the Pouletts, to raise land values since, as it was noted in 1794, effective field drainage here would 'advance its value ten or fifteen shillings an acre and make it as good land as any in the country'. ${ }^{21}$ On securing an Enclosure Act, the Pouletts subdivided the manor into small parcels for profitable disposal, and by 1820 it had passed into the possession of a variety of modest local farmers. Rhines were dug across the former common lands of Kenn Moor to the East and the improved marshland divided into 170 small allotments, most of which had become engrossed under the control of a relatively small number of tenant farmers by $1820 .^{22}$

The fractured nature of landownership at Kenn was reflected in patterns of employment. Despite its modest acreage, in 1829 the parish's adult population of 276 might find employment on no less than fourteen farms. This was more than in neighbouring Tickenham (over twice the acreage and nearly twice the population) which supported eleven. But Kenn's farms were generally small concerns and employment limited. There was, moreover, virtually no employment available in the parish outside the agricultural sector, ${ }^{23}$ although the neighbouring parish of Clevedon, developing rapidly as a seaside leisure town, offered more varied opportunities, especially in female domestic service. Given that Somerset women rarely earned more than seven pence a day for agricultural work at this time, ${ }^{24}$ the pull exerted by Clevedon is understandable and it may have had an effect on village demography. While the population of Clevedon doubled during the 1820s, Kenn was the only parish in the district to suffer a decrease, particularly amongst its women, whose numbers dropped substantially by forty-six.

With no resident squire in the parish, there was no obvious nexus of economic power and with no resident magistrate either, no obvious political and judicial centre. Ecclesiastical care was similarly limited. Kenn was an Anglican monopoly but nevertheless only the poor northern outpost of a much larger plural benefice covering the distant parishes of North Wootton and Pilton and the adjacent parish of Yatton. The vicar, H. W. Barnard, spent much of his time at Wells where he was also a canon of the cathedral, and was at odds with his parishioners over tithe payments. In the late $1820 \mathrm{~s}$, Barnard abandoned the customary practice of receiving annual nominal sums ('hay silver') on a restricted sample of produce based upon ancient field sizes, and instead demanded full payment based upon crop volume, even on previously exempt commodities like hay and sheep. ${ }^{25}$ While these measures enabled Barnard to increase his parochial income by thirty per cent, farmers predictably offset their losses by lowering wages and employing less labour. The effect, complained the parishes, 'proves very injurious to the labourers in decreasing arable work and consequently increasing poor rates', and discontent rumbled on into the early 1830 s by which time, according to the government's tithe commissioners, Barnard was in a state of 'warfare with the occupiers of lands in Kenn'. Consequently, 'the neighbourhood for miles around was at that time in a state of the darkest ignorance' thought Leifchild, 'and, as a consequence, all manner of vice and impiety abounded'. ${ }^{26}$ At an average of seven shillings a week in 1830, Somerset's agricultural wages were already 'too low' in the view of at least one county magistrate but they were made disproportionately lower still in the West of the county by a system of 'petty truck'. Home brewed cider, too 'strong and rough' for retail in London but arbitrarily overvalued by Somerset farmers as the equivalent of one shilling and sixpence in wages per 
week, was commonly given as payment in kind so that 'in Somerset the labourer is worse off than in Wiltshire and considerably worse off than in Dorsetshire and Devonshire'. ${ }^{27}$ Low wages, considered the Bath Fournal, had made the district 'remarkable only for wretchedness and crime', and the erosion of 'every moral feeling that used to secure the social compact'. ${ }^{28}$

Whilst neighbouring parishes were sometimes charitably relieved by resident lords of the manor, there was little prospect of charity at Kenn for there had been no great landowner since the abdication of the Pouletts. Paternal care therefore resided solely with the small tenant farmers that administered the poor rate at vestry meetings, and they were not neglectful, erecting a poor house in 1817 and frequently binding pauper children as parish apprentices. ${ }^{29}$ In April 1830, a summary fine of ten shillings and sixpence imposed by magistrates upon one labourer was dispensed by the vestry to twenty-one parish paupers in a gesture as close to largesse as it could afford. ${ }^{30}$ Just as several of the defendants in the 1830 trial came from families that were frequent recipients of relief, four of the men who played a key role as plaintiffs in the prosecution, Benjamin Poole (the incendiaries' victim), Joseph Griffin (Poole's son in law), Robert Bryant and John Baker, were not only relatively successful farmers but active and regular vestrymen. There were no resident justices. The nearest, Hugh Smyth-Pigott, lived five miles away at Brockley Court while two others, William Harford and Thomas Roworth lived seven and ten miles away respectively. There were, coincidentally, two significant representatives of the county elite at relatively close quarters, the Chief Constable, George Emery, at Banwell, seven miles to the South, and the recently appointed High Sheriff, James Adam Gordon, at Naish House, just four miles to the North-East and, as we shall see, the proximity of these men may certainly have influenced the manner of the Kenn executions. However, neither they nor any of the JPs played any immediate role in parish government at Kenn. Indeed, Emery's influence proved questionable even in his home parish of Banwell the following Winter when his efforts to enrol special constables to combat Swing rioters were to collapse in a wave of local insubordination and protest. ${ }^{31}$ In these circumstances then, and buoyed by the economic, social, and political supremacy conferred upon them by the Vestry Acts of 1818 and 1819, Kenn's 'pseudo-gentry' of small farmers enjoyed an influence in the parish over and above their status as landlords and employers. ${ }^{32}$ Benjamin Poole, who owned twenty acres by 1811 and rented a further thirty, was one of the largest occupiers of land in the parish. Two less wealthy members of the same family, Richard and Mary, were also small owner-occupiers, and a fourth, Joseph, owned a beer house and three small fields, giving the Pooles a combined property interest to the value of nearly $£ 300$ per annum. ${ }^{33}$

Given the assertion that Kenn was 'infested' with the 'ill-disposed', the weakness of traditional forms of authority in the parish must be considered in the context of heightened concerns about increases in crime. During the 1820 s, the number of prisoners delivered at the county assize had nearly doubled and when in 1829 the number of prisoners awaiting trial at the summer quarter session exceeded that in the more populous manufacturing county of Yorkshire, the issue was raised in national as well as local newspapers. ${ }^{34} \mathrm{As}$ prosecution rates continued to rise, particularly for petty agricultural theft, the Lord Lieutenant was moved to remind his magistrates that however low labourers' wages had 
sunk, 'poverty cannot be admitted as an excuse' ${ }^{35}$ In common with many similar rural communities, the sparse structures in place for the maintenance of local order at Kenn were largely ineffectual in the battle to prevent agricultural pilfering, a cause of frequent frustration to both landowners and tenantry. The vestry was empowered annually to elect a single part-time constable but, as Whitehall was well aware, the county's rural police were 'most woefully inefficient in detecting and absolutely of no avail in preventing crime'. ${ }^{36}$ This was clear inside the parish too. In April 1829 for example, an attempt to prosecute a labouring man for stealing potatoes was dismissed for want of witnesses by the Grand Jury despite the affirmative testimony of the parish constable who had searched his cottage and retrieved the goods. ${ }^{37}$ The difficulty of obtaining reliable witnesses in such a close-knit community made the offering of rewards for information a virtual necessity. Following the attack on Poole's wheat mows in October, a series of reward notices, starting with an offer of $£ 30$ from Poole himself, was published by several farmers in an effort to counter further thefts of potatoes and lambs. ${ }^{38}$ None of these rewards was claimed however. Informing carried a profound social stigma, and those who sought monetary advantage from it, either by claiming a portion of the defendant's fine under the Common Informers Act, or from a reward offered independently by the plaintiff, could expect to be ostracised.

Taking pecuniary advantage from the conviction of others had by this time gained public notoriety through the widespread use of proxy informers by 'professional' operators who made a living from it in urban centres, but it was regarded with equal suspicion in the countryside. Informers in Somerset were 'deprecated by everyone' admitted a parish constable; an informer even against regrators was mobbed and beaten at Shepton Mallet in 1828, while at Middlezoy, another parish 'situated in the fens of Somersetshire, where there is no resident gentry', two tax informers were subjected to rough music by a crowd that included several prominent farmers, the High Constable and two church wardens. Defence counsel would later argue that:

Their lordships knew an informer was an odious character... the feeling was an English one and when he heard the character of an informer reprobated by men of learning and eminence, he hoped their lordships would make some allowance for individuals who, moving in a very humble sphere, suffered a similar spirit to carry them too far. ${ }^{39}$

However odious, informers were commonly used in Somerset to secure convictions against unlicensed beer and cider shops. Rhetorically at least, the seemingly secretive and unobserved character of unlicensed drinking houses complimented the clandestine character of the arsonist and heightened concerns for their surveillance. 'In all cases of assault or robbery which were brought before the sessions which I attended', reported a government commissioner in 1834, 'the beer shops were the places of rendezvous'. ${ }^{40}$ The Somerset bench began a crackdown in the summer of 1828 with a test case at Wrington which encouraged witnesses to come forward in several other communities. Exemplary fines were handed down, then and in the following year, throughout the county, ranging from a maximum of fifty pounds in the case of one Wincanton house 'notorious for irregularities' to five pounds for less malignant transgressions. ${ }^{41}$ 
These circumstances are important because the actions of an informer against a farmer for selling unlicensed cider were the principal cause of arson at Kenn. Shortly before his mows were burned, Benjamin Poole had sent a farm servant to an unlicensed cider house kept by William Wall, 'a small farmer with about fifteen acres and a cow', with instructions to purchase a drink and then testify before a supervisor of excise. ${ }^{42}$ Although his conviction was for arson, Wall clearly understood the real cause of his execution as he stood beneath the gallows and reminded the crowd, 'I should not have been here if I had not opened a cider shop'. The community politics underlying Wall's response were fairly complex, for Poole was not just a disinterested upholder of the law but a man whose brother kept a properly licensed beer house on the Yatton road, who had been in dispute with several of Wall's regular customers over various matters for some months, and who had already caused one to be taken up on suspicion of stealing his hay. For some at least of Kenn's labouring community, Poole's financial loss from incendiarism might be considered legitimate. And if the arson itself was 'covert', its public celebration was not. A week after the event, four of Wall's labourers, John and James Old, John Rowley and Richard Clark gave Poole rough music and made no attempt to conceal their identity. 'Wheeling a cask of cider opposite my house ... they stopped and sung a profane song, flung up their hats and gave a cheer', he said, making him 'afraid to go out'. ${ }^{43}$

For the next seven months however, the solidarity of the village against informers appears to have held, for no charges were laid against any of these people for incendiarism until the vestryman farmer Joseph Griffin apprehended two of them for agricultural theft the following May. Under examination, Clark and Rowley, confessed the arson and named the Old brothers as accomplices. In the course of the subsequent 'long and careful investigation' by magistrates, William and Mary Wall, and a number of other villagers, including further members of the Old and Rowley families, were also named and apprehended, the suspects collectively envisaged as a 'gang', and linked to a number of still unsolved potato and lamb thefts. It now emerged that Isaac Old, who had previously been taken up on suspicion for both theft and serious assault, had previously worked for and lodged with Wall but had been dismissed in March 1829 partly because of the 'most abandoned set ... of vile associates' he attracted to Wall's house, and partly because Wall suspected he was pilfering potatoes. Consequently, after Old secured his immunity by turning King's evidence against Wall, Clark and the Rowley brothers, Wall declared him an unreliable witness, 'incited by malice and a desire for revenge'. ${ }^{44}$ Isaac Old's possibly prejudicial evidence against Wall and his wife, the Rowley brothers and Clark was nevertheless accepted by the court, because without it there was still no clear prosecution case for incendiarism. According to the trial evidence then, Wall, motivated by a grudge against Poole for informing against his cider house, was the principal instigator, Clark and Rowley were his foot-soldiers, and Isaac Old escaped as a mere witness.

Six death sentences were delivered by judges Vaughan and Bolland on 14th August, three reprieves granted on 4th September and the executions of the remaining three set for Ilchester on 8 th September. ${ }^{45}$ At this late stage however, and without Vaughan's knowledge, the High Sheriff, James Adam Gordon, summarily ordered the execution to be switched to a field in the village. This controversial and last minute decision, which 
was not made by application to the judges in the customary manner, reflected shifting local feelings about the effectiveness of the trial. Initial relief that the parish had been delivered from 'a most daring gang of thieves and miscreants' faded in the days after their conviction amid newspaper assertions that the parish remained insubordinate and that the condemned men were displaying a 'hardened indifference' to their fate. On 31st August, a burglary in a neighbouring parish during which a shotgun was stolen, was ascribed by the press to men 'supposed to be part of the incendiaries gang', while the following week's edition of the Bristol Mirror claimed:

The neighbourhood of Kenn has still been the scene of frequent plunder, and in the hope that the fate of the unfortunate men might have a more salutary effect upon such of the gang as are still at large, it was determined that the execution should take place near the spot where the crime had been committed. ${ }^{46}$

Although there had been no crime-scene executions in Somerset for three decades, the decision in 1801 to hang two food rioters at Taunton, 'instead of Ilchester, by way of stronger example', had satisfied the magistracy by lodging itself firmly in collective memory; indeed it had been recalled in the local press as recently as 1829 . 'It is commonly reported', wrote a much later Victorian chronicler, 'that these poor wretches were conveyed to the gallows in a wagon, each one having to sit upon his coffin'. And the example would now be repeated. ${ }^{47}$

The judicial cavalcade that therefore brought the condemned from Ilchester to Kenn on 8th September was an extravagant one, headed by Chief Constable George Emery with one hundred special constables, and High Sheriff Gordon. Behind them, an open coach carried the prison chaplain and the three magistrates who lived closest to the village. Finally came the prison caravan containing Wall, Rowley and Clark, together with their coffins, the prison governor and the executioner, guarded in front and behind by two parties of javelin men and fifty mounted constables. At the designated field, a troop of yeomanry and further force of constables awaited them, all drawn carefully by Emery from amongst the tenantry and neighbouring 'respectable yeomen' of the landowners Hugh Smyth-Piggot and Sir Abraham Elton of Clevedon. ${ }^{48}$ The prominence of Emery and Gordon in the procession was assured by their seniority in the hierarchy of the county executive, but more importantly perhaps, as has already been indicated, by their importance to the more local geography of the region. At Naish Court in the neighbouring parish of Clapton, Gordon had already established himself as an active squire and agricultural improver. The dynamism he brought to his more recent appointment as Sheriff can be seen in his revitalisation of the county javelin men, who appeared at Kenn without their customary tri-corn hats but in smart chapeau bras, colourful uniforms and with new javelins, each decorated with Gordon's initials and brass cross hatchets. ${ }^{49}$

Gordon's intention at Kenn was undoubtedly to create a lasting impression of judicial and hierarchical order on a poorly governed parish in inconvenient and embarrassing proximity to the well regulated regime he had established in his own. Certainly the executions had a salutary effect upon the Old family for both Isaac and James found it necessary to leave Kenn and move to the adjacent parish of Yatton. ${ }^{50}$ However, the internecine politics of the parish do not appear to have become settled either by the 
hangings or by the removal of the Olds. Two months after the executions, Poole's brother Joseph was pulled from his cart by two unidentifiable men who 'beat and kicked him in a most brutal manner without uttering a word' and in 1832, James Old revisited Kenn but was attacked by two men he believed associated with Poole. In retaliation, a crowd of men marched over from Yatton 'to beat or kill some of the bloody buggers of Kenn', precipitating an hour-long siege at a Kenn beer house during which windows were broken and a shotgun fired. It was a further week before any arrests were made, perhaps because, as an onlooker explained of his failure to fetch the parish constable, 'if I did I was in danger of my life'. The county press thought it 'extraordinary' that this 'secluded and purely agricultural part of the country' should remain 'perennially disturbed' some two years after the hangings. ${ }^{51}$ But it was not that events had been forgotten. For the next forty years at least, the carriage in which Gordon had travelled to the execution remained on display in a local cherry orchard and as late as 1914, news reporters were ushered into farmhouses to be shown carefully preserved fragments of the execution wagon. The material culture of collective memory gradually developed a pecuniary value of its own. In 1941, one of several personalised and engraved brass buttons, cut by Gordon from his ceremonial uniform and passed into the community as a memento, re-surfaced at a charity auction in Portbury and unexpectedly fetched f7.00. Even today, some farming families at Kenn are able confidently to show visitors the exact spot in Seven Acre field where the gallows was erected in $1830 .^{52}$

The hangings at Kenn prompt a more multi-causal consideration of arson and its place in rural England than traditional approaches to the mass incendiarism of Swing have encouraged. In the intricate and often locally specific causes that lay behind them, the executions exposed many of the social and structural difficulties of rural governance and community politics, but what they reveal about associations between class development, overt and covert forms of action and typologies of 'protest', is not straightforward. In this instance a least, it would be unhelpfully reductive to regard incendiarism simply as a symptom of an ongoing war between labour and capital. Wall may have been of lower social standing than Poole, but both were employers of labour and neither owned their own farmhouse. Although touched upon by uneven master-servant relations, the arsonists' principal grievance against Poole was not directly related to his status but to his betrayal of a village cider house by means that were widely considered underhand. Unlicensed houses like Wall's were ubiquitous in English villages; they cannot have operated in secrecy for they depended for their survival upon the sanction, solidarity and discretion of the whole community. The openness with which the Walls and their labourers avenged themselves and taunted their victim with rough music, indicates a popular presumption about the legitimacy of direct action against informers. If we are to see incendiarism at Kenn as an exercise in charivari justicing, we might equally understand the vigorous response of the county executive in counter-theatrical terms. Perhaps the most important lesson to be learned from Kenn is that popular ideas about incendiarism were not the sole concern of the labouring poor and the farming interest, but of the judicial authorities too, 
and historians would do well to address the strategic initiatives of magistrates, judges and sheriffs as well as labourers if we are ever to make sense of events like these. Perhaps, in other words, the meaning of the last English crime-scene execution lies less in the contribution it made to the making of a rural working class, than in the shaping of judicial intolerance towards disorderly popular culture. If, as Archer has argued, labourers could be 'selective in their choice of tactics' rather than progressively railroaded from overt to covert forms of action, ${ }^{53}$ then so too could the upholders of law and order. For at Kenn in 1830, the High Sheriff's extraordinary decision to exchange the modernity of the drop system for the backward-looking brutality of a village lynching, took place in circumstances particular to both time and place. If the firing of Poole's mows had been accompanied by collective protests against machinery, low wages or poor conditions of labour, the execution would perhaps have received attention from rural social historians before now and the incendiaries considered as emissaries of Captain Swing. But the Kenn incendiaries were put to death at the scene of their crime for a complex and interconnected set of reasons. Partly it was to uphold the principle of informing in a rural community whose dysfunctional social relations made the practice a judicial necessity. Kenn may not have been alone in satisfying these criteria, but in being virtually overlooked from the High Sheriff's own crenulated turrets and just a few miles from the house of the Chief Constable, its symbolic geography as a disorderly centre with regulated peripheries made it significantly unique. And despite Chief Constable Emery's stated wish for the initiative to be taken up and repeated in any number of similarly disorderly parishes in the aftermath of Swing, its thoroughly anachronistic nature and the distinct peculiarities of the locale may both be seen in the very fact that no such repetition occurred. Only through an appreciation of the local conditions that produced it, can the Kenn hanging and the minor act of arson that preceded it begin to make sense.

\section{Notes}

1. David Jones, 'Thomas Campbell Foster and the Rural Labourer: Incendiarism in East Anglia in the 1840s', Social History, 1 (1976), 5.

2. E. J. Hobsbawm and George Rudé, Captain Swing (London, 1969), examined rural protest across the whole of southern England but was necessarily limited to the labourers' revolt of 1830 and did not interest itself in incendiarism as cultural practice in the wider rural social relations of rural communities, but as a signifier of 'popular protest'. For later, more specific work on rural incendiarism the key text is John E. Archer, 'By a Flash and a Scare': Incendiarism, Animal Maiming and Poaching in East Anglia, 1815-1870 (Oxford, 1990), which established little or no correlation between parishes disturbed by Swing in 1830 and those disturbed by arson over a longer period (see p. 131). For subsequent studies see R. W. Ambler, 'Ranters and Rick Burners: Primitive Methodism and Rural Discontent in South Lincolnshire', in Dinah Tyszka, Keith Miller, and G. F. Bryant (eds.), Land, People and Landscapes: Essays on the History of the Lincolnshire Region (Lincoln, 1991); Janet Gyford, Men of Bad Character: The Witham Fires of the 1820s (Studies in Essex history, 1, Chelmsford, 1991); Stephen Hussey and Laura Swash, 'Horrid Lights': 19th-century Incendiarism in Essex (Studies in Essex history, 5, Chelmsford 1994); Adrian Randall and Edwina Newman, 'Protest, Proletarians and Paternalists: Social Conflict in Rural Wiltshire, 1830-1850', Rural History, 6, 2, (1995). For Charlesworth see 'An Agenda for Historical Studies of Rural Protest in Britain, 1750-1850', Rural History, 2, 2 (1991). 
3. The relationship between arson, 'social crime' and a perceived switch from covert to overt forms of social protest in the rural South forms the backbone to debates in M. Reed and R. Wells (eds.), Class Conflict and Protest in the English Countryside, 1700-1880 (London, 1990), which, as its title suggests, is preoccupied with the development of an 'English rural proletariat' and in which the earlier sallies of the 'Wells-Charlesworth debate' are collated and further explored. For a useful critique, see John Archer's contribution, 'The WellsCharlesworth Debate: A Personal Comment on Arson in Norfolk and Suffolk'; Charlesworth, 'Agenda', 234. For a related and more recent contribution to the debate over incendiarism and 'social crime', see Timothy Shakesheff, Rural Conflict, Crime, and Protest: Herefordshire, 1800 to 1860 (Woodbridge, 2003). For an overview from an earlier period that does not confine itself to reading arson as protest, see Bernard Capp, 'Arson, Threats of Arson and Incivility in Early Modern England', in Peter Burke, Brian Harrison and Paul Slack (eds), Civil Histories: Essays presented to Sir Keith Thomas (Oxford, 2000).

4. Archer, Flash and a Scare, pp. 157-8; Charlesworth, 'Agenda', 235. An honourable exception to the rule is Carl Griffin, whose 'Policy on the Hoof: Sir Robert Peel, Sir Edward Knatchbull and the Trial of the Elham Machine Breakers, 1830', Rural History, 15, 2 (2004) has made an important contribution to the historiography of judicial responses to Swing. Griffin's most recent work problematizes the relationship between patterns of newspaper reporting and the known geography of incendiarism, but is not an exploration of language as such: C. J. Griffin, 'Knowable Geographies? The Reporting of Incendiarism in the Eighteenth and early Nineteenth Century Provincial Press', Fournal of Historical Geography, 32, 1 (2006).

5. In October 1830, the Elham defendants received sentences of just four days in gaol rather than the maximum sentence of seven years transportation. See Griffin, 'Policy on the Hoof', 127-9.

6. Bristol Mirror, 4th September 1830.

7. Authentick Memoirs of the Wicked Life and Transactions of Elizabeth Feffryes, Spinster, who was Executed on Saturday, March 28, 1752, for being Concerned in the Murder of her Late Uncle, $M r$. Foseph Feffryes, (London, 1752).

8. Bath Fournal, 31st August and 7th September 1772.

9. The Times, 29th April, 19th May 1841.

10. Reverend J. Leifchild, D. D., Remarkable Facts Illustrative and Confirmatory of Different Portions of Holy Scripture (London, 1867), p. 222.

11. Bath Fournal, 4th April 1748, 20th August 1764.

12. Bath Fournal, 19th September 1748.

13. The Times, 10th August 1813, 8th August 1818.

14. The Times, 3rd August 1818. Other early nineteenth century crime-scene hangings occurred at Warminster (Wilts) and Woodford (Essex) in 1813, and at Purton (Wilts) in 1819. See The Times, 18th March, 10th August 1813, 3rd August 1819.

15. Randall McGowen, 'Civilizing Punishment: The End of the Public Execution in Britain', Fournal of British Studies, 33 (July 1994), 259-261. The seminal work on the dynamic relationship between majesty, justice and mercy in the mediation of Hanoverian capital crime and punishment is Douglas Hay, 'Property, Authority and the Criminal Law', in D. Hay, P. Linebaugh, J. Rule, E. P. Thompson and C. Winslow (eds.), Albion's Fatal Tree: Crime and Society in Eighteenth Century England (London, 1975), pp. 17-63.

16. Leifchild, Remarkable Facts, p. 221.

17. Bath and Cheltenham Gazette, 27th April 1830. For the politics of law reform see especially V.A.C. Gatrell, The Hanging Tree: Execution and the English People, 1770-1868 (Oxford, 1994), pp. 263-72, 567, 602-4. Gatrell's work on the process by which public 'squeamishness' caused a rethink of execution procedures remains unsurpassed. The revising statutes were $7 \& 8$ George IV, c. 30, secs $2 \& 17$. The 1828 Act was itself amended shortly afterwards to relieve prosecutors of the burden of proving malice, and the 1837 Act of repeal for arson only 
revoked the clause relating to stacks; it did not interfere with clauses protecting buildings in which human life was, by inference, put at risk.

18. The Times, 23rd March 1830, 21st December 1830, 12th January 1831, 24th July 1835.

19. The Times, 21st September 1830.

20. The National Archive (TNA), Home Office (HO) 40/27, Colonel J. M. Muir to Lord Melbourne, 23rd December 1830 and 24th December 1830. See also the very similar advice offered by a commander in Wiltshire; Colonel Brotherton to Lord Melbourne, 3rd December 1830.

21. The Times, 29th December 1794. See also J. Rutter, Delineation of the North Western Division of the County of Somerset (1829).

22. Somerset County Record Office (SCRO), Q/RDe/135, Kenn Enclosure Award and Plans, 1810-1815; Report from the Select Committee on Labouring Poor (Allotments of Land) with the Minutes of Evidence (London, 1843), p. 16. For the development of allotment schemes in Somerset see Appendix to the First Report From the Commissioners on the Poor Laws, South Western District (London, 1834), pp. 442-3.

23. The 1841 census, the first to note individual professions, recorded eighteen farmers and forty-two agricultural labourers at Kenn. Male and female 'servants' accounted for another thirty-five people and the only other professions recorded were carpenter (four), blacksmith (one), publican (two), shoemaker (one), butcher (one), basket-maker (one) and tallow chandler (one).

24. Mr Austin's Report on the State of Agriculture in the Counties of Wiltshire, Dorset, Devon and Somerset (London, 1843), p. 8.

25. The Times, 1 st April 1831.

26. Bath Fournal, 17th January 1831; Taunton Courier, 19th January 1831; The Times, 1st April 1831. Petitions praying for the abolition of tithes were launched from North Wootton, Yatton and Kenn in January 1831; SCRO, D/P/Yat/3/2/10, Rectorial tithes payable at Kenn, 1834; Leifchild, Remarkable Facts, p. 220.

27. TNA, HO 52/9, Vincent Stuckey to Lord Melbourne, 2nd December 1830; Mr Austin's Report on the State of Agriculture in the Counties of Wiltshire, Dorset, Devon and Somerset (London, 1843), pp. 8-9, 15

28. Bath Fournal, 20th July 1829.

29. For these payments see $S C R O, S / 800$ D/P/Kenn 9/1/1, Kenn vestry minutebook, 1814-1849.

30. see SCRO, $S / 800 D / P /$ Kenn 9/1/1, Kenn vestry minutebook, 1814-1849.

31. For the Banwell disturbance see informations in SCRO, QS/R Quarter Session Rolls, Epiphany 1831.

32. For an analysis of the effects of this legislation, see Roger Wells, 'Poor Law Reform in the Rural South East: The Influence of the Sturges Bourne Acts during the Agricultural Depression, 1815-1835', Southern History, 23 (2001). The 'pseudo-gentry' is Barry Reay's term, for which see The Last Rising of the Agricultural Labourers: Rural Life and Protest in Nineteenth Century England (Oxford, 1990), p. 23.

33. Acreages calculated from Poulett's survey of 1811: SCRO, DD/SAS/C/212.

34. The World, quoted in Bath and Cheltenham Gazette, 7th April 1829.

35. Bath and Cheltenham Gazette, 24th April 1830. The Lord Lieutenant between 1819 and 1837 was the Marquis of Bath.

36. Appendix to the First Report From the Commissioners on the Poor Laws, South Western District (Parliamentary Papers, London, 1834), p. 448.

37. For Thomas Hedges's prosecution, see SCRO QS/R, Quarter Session Rolls (microfilm), information of Abraham Davis, constable of Kenn, and John Cox, yeoman, 29th April 1829.

38. Bath Fournal, 21st December 1829; Bath and Cheltenham Gazette 27th April 1830; Times, 26th May 1830. 
39. M. McGarvie (ed.), Crime and Punishment in Regency Frome: The Fournals of Isaac Gregory, Constable of Frome, 1813-14 and 1817-18 (Frome, 1984), p. 22. For the Shepton Mallet case see $S C R O, Q / S R$, Quarter session rolls, Epiphany 1829, information of David Caddy and Isaac Norton, 24th October 1828; for Middlezoy see Bath Chronicle, 28th November 1820.

40. Appendix to the First Report From the Commissioners on the Poor Laws, South Western District (Parliamentary Papers, London, 1834), p. 448; Bristol Mirror, 11 th September 1830; TNA, HO 52/9, Robert Gunsley Ayerst to Lord Melbourne, 6th December 1830; Report from the Select Committee of the House of Lords appointed to inquire into the State of Agriculture in England and Wales with the Minutes of Evidence (London, 1837), p. 302.

41. For Somerset cider license prosecutions, see Bath and Cheltenham Gazette, 12th February 1828, 17th March 1829; Bath Chronicle, 21st August 1828; Bath Fournal, 15th August 1829; Felix Farley's Bristol Fournal, 1st July and 15th August, 1829; SCRO, QS/R Quarter Session rolls, Easter 1829, information of Joseph Humphries.

42. Bristol Mirror, 28th August 1830.

43. Bristol Mirror, 28th August 1830.

44. Bristol Mirror, 28th August 1830, TNA, HO 17/128, petition of Sarah Coliford, October 1831; petition of William Wall (n.d.), August 1830.

45. TNA, HO 17/128, memorandum of John Vaughan, 4th September 1830. For the expectation that the sentences would be carried out at Ilchester, see also Bristol Mirror, 4th September 1830. Mary Wall was still at Ilchester a year later when her mother petitioned the crown for a pardon without success. See TNA HO 17/128, petition of Sarah Coliford, October 1831.

46. Bristol Mercury, 7th September 1830; Bristol Mirror, 28th August 1830; 11th September 1830.

47. The Times, 22nd April 1801; Taunton Courier 29th July 1829; A. L. Humphreys, Materials for the History of the Town of Wellington (London and Wellington, 1889), p. 201.

48. Bristol Mirror, 11th September 1830.

49. Bath Chronicle, 10th April 1828.

50. They appear in the 1841 Yatton census as James and Isaac Ould.

51. SCRO, $Q / A G i / 14 / 4$, Ilchester Felons Register, 1828-33, prisoners for Michaelmas Sessions, October 1832; QS/R, Quarter Session Rolls (microfilm), information of Samuel Coleman, John Parsons, Samuel Rawlings and others, 8th October 1832; Q/Sca 1-30, Somerset assize calendar, March 1831; Bristol Gazette, 16 November 1830; Leifchild, Remarkable Facts, p. 224.

52. Clevedon Mercury, 24th February 1923, 13th December 1941; Bristol Evening World, 9th August 1952; Weston Mercury, 13th August 1954. I am indebted to two local historians, Ken Crowhurst of the Gordano Society and Ann Bessell of Bristol for their help with these more recent news cuttings.

53. Archer, 'The Wells-Charlesworth Debate', p. 86. 